\title{
Detecting influenza and emerging avian influenza virus by influenza and pneumonia surveillance systems in a large city in China, 2005 to 2016
}

\author{
Xiaorong Guo ${ }^{1+}$, Dong Yang ${ }^{2+}$, Ruchun $\mathrm{Liu}^{2+}$, Yaman $\mathrm{Li}^{2}$, Qingqing $\mathrm{Hu}^{3}$, Xinrui Ma', Yelan $\mathrm{Li}^{2}$, Heng Zhang ${ }^{2}$, \\ Xixing Zhang ${ }^{2}$, Benhua Zhao ${ }^{1+}$ and Tianmu Chen ${ }^{1 *+}$ (D)
}

\begin{abstract}
Background: Detecting avian influenza virus has become an important public health strategy for controlling the emerging infectious disease.

Methods: The HIS (hospital information system) modified influenza surveillance system (ISS) and a newly built pneumonia surveillance system (PSS) were used to monitor the influenza viruses in Changsha City, China. The ISS was used to monitor outpatients in two sentinel hospitals and to detect mild influenza and avian influenza cases, and PSS was used to monitor inpatients in 49 hospitals and to detect severe and death influenza cases.

Results: From 2005 to 2016, there were 3,551,917 outpatients monitored by the ISS system, among whom 126,076 were influenza-like illness (ILI) cases, with the ILI proportion (ILI\%) of 3.55\%. After the HIS was used, the reported incident cases of ILI and ILI\% were increased significantly. From March, 2009 to September, 2016, there were 5,491, 560 inpatient cases monitored by the PSS system, among which 362,743 were pneumonia cases, with a proportion of $6.61 \%$. Among pneumonia cases, about $10.55 \%(38,260 / 362,743)$ of cases were severe or death cases. The pneumonia incidence increased each year in the city. Among 15 avian influenza cases reported from January, 2005 to September, 2016, there were 26.7\% (4/15) mild cases detected by the HIS-modified ISS system, while 60.0\% (9/ 15) were severe or death cases detected by the PSS system. Two H5N1 severe cases were missed by the ISS system in January, 2009 when the PSS system was not available.
\end{abstract}

Conclusions: The HIS was able to improve the efficiency of the ISS for monitoring ILI and emerging avian influenza virus. However, the efficiency of the system needs to be verified in a wider area for a longer time span in China.

Keywords: Avian influenza virus, Influenza surveillance system, Pneumonia surveillance system

\section{Background}

In recent years, reports about human cases of infected emerging avian influenza virus has become more and more common [1-4]. Human infected H5N1 virus was first

\footnotetext{
* Correspondence: 13698665@qq.com

'Xiaorong Guo, Dong Yang, and Ruchun Liu contributed equally to this study.

${ }^{\dagger}$ Benhua Zhao and Tianmu Chen senior authors contributed equally to this study.

${ }^{1}$ State Key Laboratory of Molecular Vaccinology and Molecular Diagnostics, School of Public Health, Xiamen University, 4221-117 South Xiang'an Road, Xiang'an District, Xiamen, Fujian Province, People's Republic of China Full list of author information is available at the end of the article
}

reported in 1997 in Hong Kong, China, and then was spread widely in mainland China [5] as well as many other countries in Southeast Asia [6, 7], West Asia [8, 9], and Africa [10]. Thereafter, human cases infected with emerging influenza viruses were reported in the subsequent years, especially in China. For example, H7N9 was reported in 2013 [11], H5N6 in 2014 [2, 12-15], H10N8 in 2013 [1], and H9N2 in 2013 in Hunan province, China [16]. It is important to detect these emerging viruses in and out of China.

There are currently two main surveillance systems focused on detecting / monitoring the virus in China. One is China's national sentinel surveillance system for influenza-

(c) The Author(s). 2019 Open Access This article is distributed under the terms of the Creative Commons Attribution 4.0 International License (http://creativecommons.org/licenses/by/4.0/), which permits unrestricted use, distribution, and 
like illness (ILI) in sentinel hospitals across 31 provinces in mainland China. The sentinel hospitals are accounted for $2.5 \%$ of all hospitals in China [17]. The other one is the national pneumonia surveillance system, which was built by the Chinese Center for Disease Control and Prevention (CDC) in 2004. The system is mainly to monitor pneumonia of unknown etiology (PUE) to facilitate timely detection of novel respiratory pathogens, such as severe acute respiratory syndrome (SARS) and avian influenza [18]. The two systems have played significant roles in monitoring the activity of influenza, controlling and preventing emerging avian influenza [17-19].

Traditionally, the number of ILI cases was counted manually by influenza surveillance staff. Therefore, the hospital information system (HIS) has been used for recording and monitoring the outpatients in most hospitals in China [20, 21]. The PUE surveillance system was not (and is still not) used consistently because most cases on community-acquired pneumonia met the PUE criteria, but were not reported to the PUE system [18]. The PUE surveillance system was not sensitive enough to detect the emerging avian influenza virus.

To explore a new way to monitor influenza virus by using HIS and improve the sensitivity of detecting emerging avian influenza virus, we modified the influenza surveillance system (ISS) and built a pneumonia surveillance system (PSS) in Changsha City, China. In this study, we separately reported the roles of the ISS and the PSS systems in detecting influenza and emerging avian influenza virus.

\section{Methods}

\section{Study area}

Changsha $\left(27^{\circ} 51^{\prime} \sim 28^{\circ} 41^{\prime} \mathrm{N}, 111^{\circ} 53^{\prime} \sim 114^{\circ} 15^{\prime} \mathrm{E}\right)$, a large city with 7.04 million people in central south China, is the capital of Hunan Province. It includes 6 districts, 2 counties, and 1 county-level city. There are a total of 4586 hospitals, clinics, and public health departments all over the city. In this study, there were 49 secondary and tertiary hospitals included into the PSS system and 2 tertiary hospitals into the ISS system, respectively. The two hospitals in ISS system were also included in the PSS. The locations of the selected hospitals were shown in Fig. 1.

\section{The modified influenza surveillance system}

The ISS, based on two sentinel hospitals (hospitals A and B), was set up in Changsha in September 2005. Hospital A, which is located in the south urban area of the city, is a tertiary hospital with more than 2700 staffs and 1839 hospital beds. Hospital B, which is located in the north urban area of the city, is also a tertiary hospital with more than 1700 staffs and 1593 hospital beds. Both hospitals have the administrative department that is in charge of the routine surveillance. Hospital A is a municipally designated hospital for the diagnosis and treatment of tuberculosis.

In 2006 and 2008, the ISS system became a branch of Hunan provincial and national influenza surveillance network respectively. In February, 2012, the HIS was adopted for the surveillance in hospital A, and was modified after June, 2013. The ISS in Changsha underwent five stages (stage 1: week 39, 2005 to week 52, 2005; stage 2: week 1, 2006 to week 52, 2007; stage 3: week 1, 2008 to week 5, 2012; stage 4: week 6, 2012 to week 24, 2013; stage 5: week 25, 2013 to week 41, 2016.). During stage 1 to 3, the two sentinel hospitals registered ILI cases manually in five outpatient departments, including outpatient and emergency departments of respiratory medicine, outpatient and emergency departments of pediatrics, and fever clinic. During stage 4 to 5 , hospital $\mathrm{B}$ remained the manual surveillance in the same outpatient departments. ILI case was defined as "fever (axillary temperature $\geq 38^{\circ} \mathrm{C}$ ) + cough or sore throat" [22, 23].

Differently, in hospital A, HIS was adopted into the ISS during stage 4 to 5 and was also named as "HIS (stage 1)" and "HIS (stage 2)" respectively. During stage 4, all outpatient departments of the hospital were included in the ISS, and the computer would emerge a popup window by HIS with the question that "ILI or not" if physicians diagnosed one of the 108 influenzaassociated diseases based on the International Classification of Diseases 10th Revision (ICD-10). The physician should answer the question to continue the later part to treat the diseases from the patients. But we found that some ILI cases could still be missed probably because of the misunderstanding of the definition of ILI of the physician, especially if the physician was not in the department with the ISS system during stage 1 to 3 . Therefore, during stage 5 , the question was changed to three options: a) fever (axillary temperature $\geq 38^{\circ} \mathrm{C}$ ), b) cough, c) sore throat. The procedure of HIS would count the ILI automatically by computing the number of "a) + b)", “a) + c)", and “a) + b) + c)".

During the 5 stages, the patients who visited the outpatient departments of the two hospitals and were identified as potential ILI cases, were calculated every week. At least 5-20 throat swab samples of ILI cases per hospital per week were collected for testing the influenza virus by reverse transcription polymerase chain reaction (RT-PCR) and / or cell culture in the laboratory of Changsha CDC. The criteria for including ILI patients who were chosen to collect the samples were: a) the patients were in three days after illness onset date; b) the patients had no history of using antivirals. These sample selection and laboratory surveillance procedures were based on the National Influenza Surveillance Program (2010 edition and 2017 edition) which was announced by the National Health Commission of the People's 


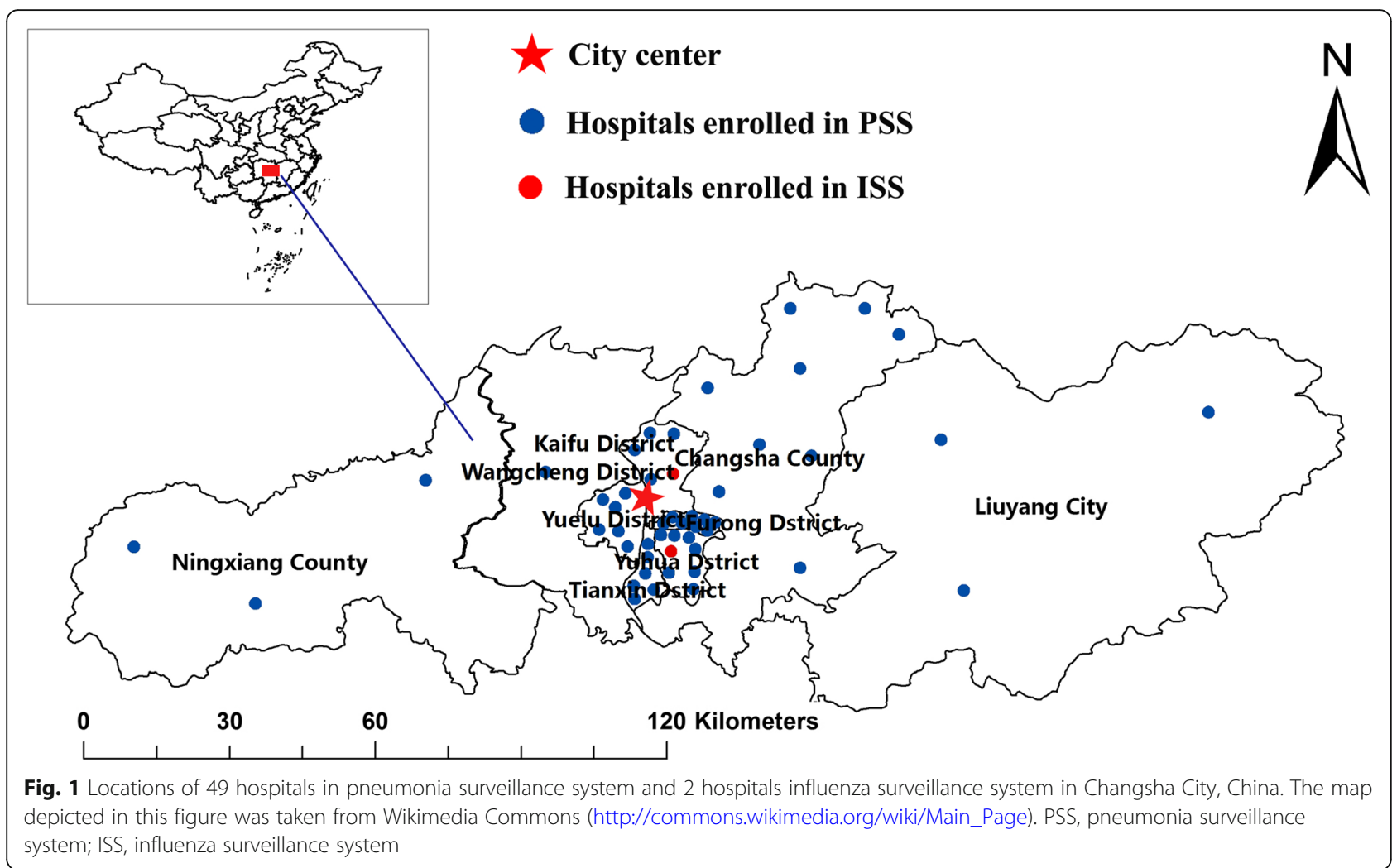

Republic of China. This system may monitor influenza and emerging avian influenza cases with mild symptoms or at the early stage of the infection (Fig. 2). Data of the system from week 39, 2005 to week 41, 2016 were collected in our study. Because H1N1pdm was firstly emerged in 2009 [24, 25], the virus was not tested in ISS stages 1 and 2 (Table 1 ).

\section{The new pneumonia surveillance system}

The PSS was built in Changsha in March, 2009. Pneumonia related inpatient departments in all 49 hospitals (excluding the primary health care centers and private clinics) in Changsha were enrolled into the system. This system monitors pneumonia cases among inpatient population. The public health staff in the surveillance hospitals would count the total number of monitored inpatients, pneumonia cases, severe or death pneumonia cases diagnosed by physicians and then they reported to CDC monthly. When cases were suspected as infected with avian influenza virus by clinicians, the throat swab or lower respiratory tract samples of the suspicious patients (either pneumonia cases, severe or death pneumonia cases) were collected for testing the virus by RT-PCR in the laboratory of Changsha CDC. All the surveillance procedures were performed in every month of each year. However, because H5N6 was first emerged in 2014 and H7N9 in 2013 in China [2, 12, 15, 17], the viruses were not tested from ISS stage 1 to 4 , and from ISS stage 1 to 3 , respectively (Table 1 ). The PSS system may monitor influenza and emerging avian influenza cases with severe symptoms or death (Fig. 2). In this study, we collected the data of the system from March, 2009 to September, 2016.

\section{Statistical methods}

The sentinel hospitals A and B are located in the south and north in the same city. We assumed that the outpatients were from the same age group. Therefore, three indicators $\left(d_{1}, d_{2}\right.$ and $\left.d_{3}\right)$ were used to compare the difference between the two hospitals among the five stages. They were the differences of weekly number of monitored outpatients, ILI, and ILI\% of the two hospitals, and were expressed as follows:

$$
\begin{aligned}
& d_{1}=x_{A}-x_{B} \\
& d_{2}=y_{A}-y_{B} \\
& d_{3}=z_{A}-z_{B}
\end{aligned}
$$

$x_{A}, x_{B}, y_{A}, y_{B}, z_{A}$ and $z_{B}$ refer to weekly number of monitored outpatients of hospital A, weekly number of monitored outpatients of hospital B, weekly ILI of hospital A, weekly ILI of hospital B, weekly ILI\% of hospital A, and weekly ILI\% of hospital B. 


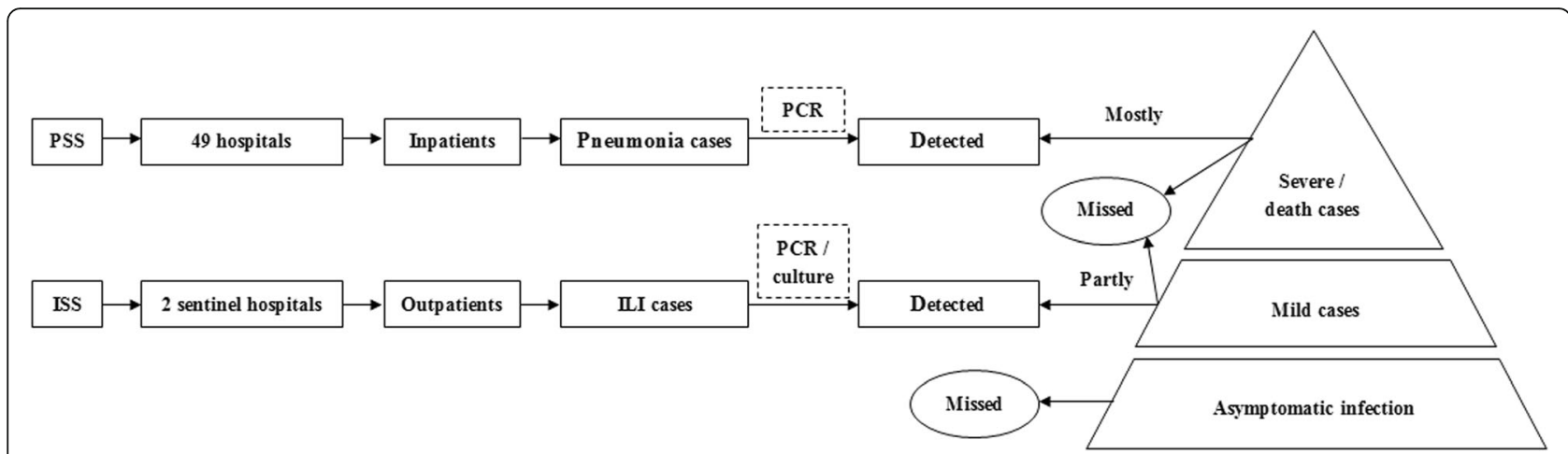

Fig. 2 Flowchart of detecting influenza and avian influenza virus by influenza surveillance system and pneumonia surveillance system in Changsha City, China. PSS, pneumonia surveillance system; ISS, influenza surveillance system; ILI, influenza-like illness; PCR, polymerase chain reaction

The Analysis of variance (ANOVA) was employed to show the $d_{1}, d_{2}$ and $d_{3}$ among the five surveillance stages of the two sentinel hospitals. If there is a statistical significance, the Least Significant Difference (LSD) method will be adopted to conduct the multiple comparisons between any two stages. $P<0.05$ was considered statistically significant.

\section{Results}

Influenza surveillance system

From week 39 (from 26th September to 2nd October) in 2005 to week 41 (from $10^{\text {th }}$ October to 16th October) in 2016, a total of 3,551,917 outpatients were monitored by the ISS system, among whom 126,076 were ILI cases, with the ILI\% of $3.55 \%$ (Table 1). From the two sentinel

Table 1 Outcomes during different surveilled stages of influenza surveillance system in Changsha City, China

\begin{tabular}{|c|c|c|c|c|c|c|c|c|c|c|c|c|c|c|c|}
\hline \multirow{2}{*}{$\begin{array}{l}\text { Sentinel } \\
\text { hospitals }\end{array}$} & \multirow[t]{2}{*}{ Stages } & \multirow{2}{*}{$\begin{array}{l}\text { Surveilled } \\
\text { patients }\end{array}$} & \multirow[t]{2}{*}{ ILI } & \multirow[t]{2}{*}{ ILLI\% } & \multirow{2}{*}{$\begin{array}{l}\text { Number } \\
\text { of tested } \\
\text { specimens }\end{array}$} & \multicolumn{10}{|c|}{ Number of positive } \\
\hline & & & & & & $\mathrm{H} 3 \mathrm{~N} 2$ & $\mathrm{H} 1 \mathrm{~N} 1$ & H1N1pdm & A (untyped) & B & H5N1 & H5N6 & H7N9 & H9N2 & Total \\
\hline \multirow[t]{6}{*}{ Hospital A } & 1 & 8203 & 188 & 2.29 & 30 & 0 & 1 & NA & 0 & 0 & 0 & NA & NA & 0 & 1 \\
\hline & 2 & 123,731 & 2100 & 1.70 & 721 & 53 & 20 & NA & 0 & 8 & 0 & NA & NA & 0 & 81 \\
\hline & 3 & 503,835 & 17,190 & 3.41 & 2692 & 47 & 31 & 188 & 59 & 64 & 0 & NA & NA & 0 & 389 \\
\hline & 4 & 379,441 & 10,014 & 2.64 & 641 & 41 & 0 & 31 & 0 & 12 & 0 & NA & 1 & 0 & 85 \\
\hline & 5 & $1,163,601$ & 66,779 & 5.74 & 3534 & 178 & 0 & 124 & 1 & 202 & 0 & 1 & 0 & 2 & 508 \\
\hline & Total & $2,178,811$ & 96,271 & 4.42 & 7618 & 319 & 52 & 343 & 60 & 286 & 0 & 1 & 1 & 2 & 1064 \\
\hline \multirow[t]{6}{*}{ Hospital B } & 1 & 7754 & 452 & 5.83 & 29 & 0 & 1 & NA & 0 & 0 & 0 & NA & NA & 0 & 1 \\
\hline & 2 & 177,460 & 2089 & 1.18 & 596 & 50 & 30 & NA & 0 & 1 & 0 & NA & NA & 0 & 81 \\
\hline & 3 & 479,086 & 13,045 & 2.72 & 2626 & 58 & 52 & 171 & 46 & 73 & 0 & NA & NA & 0 & 400 \\
\hline & 4 & 174,345 & 2382 & 1.37 & 651 & 43 & 0 & 30 & 0 & 8 & 0 & NA & 0 & 0 & 81 \\
\hline & 5 & 534,461 & 11,837 & 2.21 & 3393 & 151 & 0 & 66 & 0 & 172 & 0 & 0 & 0 & 0 & 389 \\
\hline & Total & $1,373,106$ & 29,805 & 2.17 & 7295 & 302 & 83 & 267 & 46 & 254 & 0 & 0 & 0 & 0 & 952 \\
\hline \multirow[t]{6}{*}{ Total } & 1 & 15,957 & 640 & 8.12 & 59 & 0 & 2 & NA & 0 & 0 & 0 & NA & NA & 0 & 2 \\
\hline & 2 & 301,191 & 4189 & 2.87 & 1317 & 103 & 50 & NA & 0 & 9 & 0 & NA & NA & 0 & 162 \\
\hline & 3 & 982,921 & 30,235 & 6.13 & 5318 & 105 & 83 & 359 & 105 & 137 & 0 & NA & NA & 0 & 789 \\
\hline & 4 & 553,786 & 12,396 & 4.01 & 1292 & 84 & 0 & 61 & 0 & 20 & 0 & NA & 1 & 0 & 166 \\
\hline & 5 & $1,698,062$ & 78,616 & 7.95 & 6927 & 329 & 0 & 190 & 1 & 374 & 0 & 1 & 0 & 2 & 897 \\
\hline & Total & $3,551,917$ & 126,076 & 3.55 & 14,913 & 621 & 135 & 610 & 106 & 540 & 0 & 1 & 1 & 2 & 2016 \\
\hline
\end{tabular}


Table 2 Multiple comparisons of surveilled patients, ILI and ILI\% among different stages between two sentinel hospitals based on Least Significant Difference method

\begin{tabular}{|c|c|c|c|c|}
\hline $\begin{array}{l}\text { Dependent } \\
\text { variables }\end{array}$ & Stages (I) & Stages $(J)$ & $\begin{array}{l}\text { Mean difference } \\
(I-J)\end{array}$ & $P$ \\
\hline \multirow[t]{20}{*}{ Surveilled patients } & \multirow[t]{4}{*}{ Stage 1} & Stage 2 & $548.7\left(^{\mathrm{a}}\right)$ & 0.006 \\
\hline & & Stage 3 & -83.6 & 0.667 \\
\hline & & Stage 4 & $-2856.6\left(^{(a)}\right.$ & $<0.001$ \\
\hline & & Stage 5 & $-3583.7\left({ }^{\mathrm{a}}\right)$ & $<0.001$ \\
\hline & \multirow[t]{4}{*}{ Stage 2} & Stage 1 & $-548.7\left({ }^{\mathrm{a}}\right)$ & 0.006 \\
\hline & & Stage 3 & $-632.3\left(^{\mathrm{a}}\right)$ & $<0.001$ \\
\hline & & Stage 4 & $-3405.3\left(^{(a)}\right.$ & $<0.001$ \\
\hline & & Stage 5 & $-4132.4\left(^{(\mathrm{a})}\right.$ & $<0.001$ \\
\hline & \multirow[t]{4}{*}{ Stage 3} & Stage 1 & 83.66 & 0.667 \\
\hline & & Stage 2 & $632.3^{(\mathrm{a})}$ & $<0.001$ \\
\hline & & Stage 4 & $-2773.0\left(^{(a)}\right)$ & $<0.001$ \\
\hline & & Stage 5 & $-3500.1\left(^{(a)}\right.$ & $<0.001$ \\
\hline & \multirow[t]{4}{*}{ Stage 4} & Stage 1 & $2856.6\left(^{\mathrm{a}}\right)$ & $<0.001$ \\
\hline & & Stage 2 & $3405.3\left(^{(\mathrm{a})}\right.$ & $<0.001$ \\
\hline & & Stage 3 & $2773.0\left(^{(a)}\right.$ & $<0.001$ \\
\hline & & Stage 5 & $-727.1\left(^{\mathrm{a}}\right)$ & $<0.001$ \\
\hline & \multirow[t]{4}{*}{ Stage 5} & Stage 1 & $3583.7\left(^{\mathrm{a}}\right)$ & $<0.001$ \\
\hline & & Stage 2 & $4132.4\left({ }^{(a}\right)$ & $<0.001$ \\
\hline & & Stage 3 & $3500.1\left(^{(\mathrm{a})}\right.$ & $<0.001$ \\
\hline & & Stage 4 & $727.1^{(\mathrm{a})}$ & $<0.001$ \\
\hline \multirow[t]{20}{*}{ ILI } & \multirow[t]{4}{*}{ Stage 1} & Stage 2 & -19.0 & 0.557 \\
\hline & & Stage 3 & -38.2 & 0.222 \\
\hline & & Stage 4 & $-126.4\left(^{(\mathrm{a})}\right.$ & $<0.001$ \\
\hline & & Stage 5 & $-334.6\left(^{\mathrm{a}}\right)$ & $<0.001$ \\
\hline & \multirow[t]{4}{*}{ Stage 2} & Stage 1 & 19.0 & 0.557 \\
\hline & & Stage 3 & -19.3 & 0.156 \\
\hline & & Stage 4 & $-107.4\left(^{\mathrm{a}}\right)$ & $<0.001$ \\
\hline & & Stage 5 & $-315.7\left(^{a}\right)$ & $<0.001$ \\
\hline & \multirow[t]{4}{*}{ Stage 3} & Stage 1 & 38.2 & 0.222 \\
\hline & & Stage 2 & 19.3 & 0.156 \\
\hline & & Stage 4 & $-88.1^{(\mathrm{a})}$ & $<0.001$ \\
\hline & & Stage 5 & $-296.4\left(^{\mathrm{a}}\right)$ & $<0.001$ \\
\hline & \multirow[t]{4}{*}{ Stage 4} & Stage 1 & $\left.126.4^{\mathrm{a}}\right)$ & $<0.001$ \\
\hline & & Stage 2 & $107.4^{(\mathrm{a})}$ & $<0.001$ \\
\hline & & Stage 3 & $88.1\left(^{(\mathrm{a})}\right.$ & $<0.001$ \\
\hline & & Stage 5 & $-208.3\left(^{(a)}\right.$ & $<0.001$ \\
\hline & \multirow[t]{4}{*}{ Stage 5} & Stage 1 & $\left.334.6{ }^{\mathrm{a}}\right)$ & $<0.001$ \\
\hline & & Stage 2 & $315.7^{(\mathrm{a})}$ & $<0.001$ \\
\hline & & Stage 3 & $296.4\left(^{\mathrm{a}}\right)$ & $<0.001$ \\
\hline & & Stage 4 & $208.3^{(\mathrm{a})}$ & $<0.001$ \\
\hline \multirow[t]{2}{*}{ ILI\% } & \multirow[t]{2}{*}{ Stage 1} & Stage 2 & $-5.3\left(^{(}\right)$ & $<0.001$ \\
\hline & & Stage 3 & $-5.9\left(^{(\mathrm{a})}\right.$ & $<0.001$ \\
\hline
\end{tabular}

Table 2 Multiple comparisons of surveilled patients, ILI and ILI\% among different stages between two sentinel hospitals based on Least Significant Difference method (Continued)

\begin{tabular}{|c|c|c|c|c|}
\hline $\begin{array}{l}\text { Dependent } \\
\text { variables }\end{array}$ & Stages (I) & Stages (J) & $\begin{array}{l}\text { Mean difference } \\
(I-J)\end{array}$ & P \\
\hline & & Stage 4 & $-6.1\left(^{\mathrm{a}}\right)$ & $<0.001$ \\
\hline & & Stage 5 & $-8.4\left(^{\left({ }^{a}\right)}\right.$ & $<0.001$ \\
\hline & Stage 2 & Stage 1 & $\left.5.3^{\mathrm{a}}\right)$ & $<0.001$ \\
\hline & & Stage 3 & $-0.6\left(^{\mathrm{a}}\right)$ & 0.029 \\
\hline & & Stage 4 & $-0.8\left(^{\left({ }^{a}\right)}\right.$ & 0.018 \\
\hline & & Stage 5 & $-3.1\left(^{(\mathrm{a})}\right.$ & $<0.001$ \\
\hline & Stage 3 & Stage 1 & $5.9\left(^{\mathrm{a}}\right)$ & $<0.001$ \\
\hline & & Stage 2 & $0.6^{(\mathrm{a})}$ & 0.029 \\
\hline & & Stage 4 & -0.2 & 0.452 \\
\hline & & Stage 5 & $-2.5\left(^{\mathrm{a}}\right)$ & $<0.001$ \\
\hline & Stage 4 & Stage 1 & $6.1^{(\mathrm{a})}$ & $<0.001$ \\
\hline & & Stage 2 & $\left.0.8^{\mathrm{a}}\right)$ & 0.018 \\
\hline & & Stage 3 & 0.2 & 0.452 \\
\hline & & Stage 5 & $-2.3\left(^{\left({ }^{a}\right)}\right.$ & $<0.001$ \\
\hline & Stage 5 & Stage 1 & $8.4^{(\mathrm{a})}$ & $<0.001$ \\
\hline & & Stage 2 & $\left.3.1^{\mathrm{a}}\right)$ & $<0.001$ \\
\hline & & Stage 3 & $2.5^{(\mathrm{a})}$ & $<0.001$ \\
\hline & & Stage 4 & $\left.2.3^{\mathrm{a}}\right)$ & $<0.001$ \\
\hline
\end{tabular}

a The mean difference is significant at the 0.05 level. ILI, influenza-like illness

hospitals, the total monitored outpatients numbers were $2,178,811$ and 1,373,106, ILI were 96,271 and 29,805, and ILI\% were 4.42 and $2.17 \%$, respectively (Table 1 ).

The results of ANOVA showed that the $d_{1}, d_{2}$ and $d_{3}$ were significantly different among the five surveillance stages $(P<0.001)$. The results of multiple comparisons by LSD method showed a significant difference in the number of outpatients monitored weekly between hospital A and $\mathrm{B}$ between any two stages except between stage 1 and 3. The weekly ILI in hospital A during stage 4 and 5 were shown to be statistically significant compared to hospital $\mathrm{B}$, but no statistical significance during the stages from 1 to 3. The weekly numbers of ILI\% in hospital A were shown significance to hospital B during almost all stages except between stage 3 and 4 (Table 2). These results indicated that HIS could improve the efficiency of ISS system in monitoring ILI and ILI\% significantly (Fig. 3).

The seasonality of ILI in hospital A matched the activity of influenza virus better than hospital B after the use of HIS (Fig. 4). Two ILI peaks were almost recorded in each year from the ISS system during stages 4 and 5 in hospital A. One peak was recorded in the alternation of winter to spring, and the other one was in summer (Fig. 4). However, the seasonality of ILI was not shown in hospital B. Because of the HIS, the proportion of tested sample descended in hospital A. However, the proportion of positive 


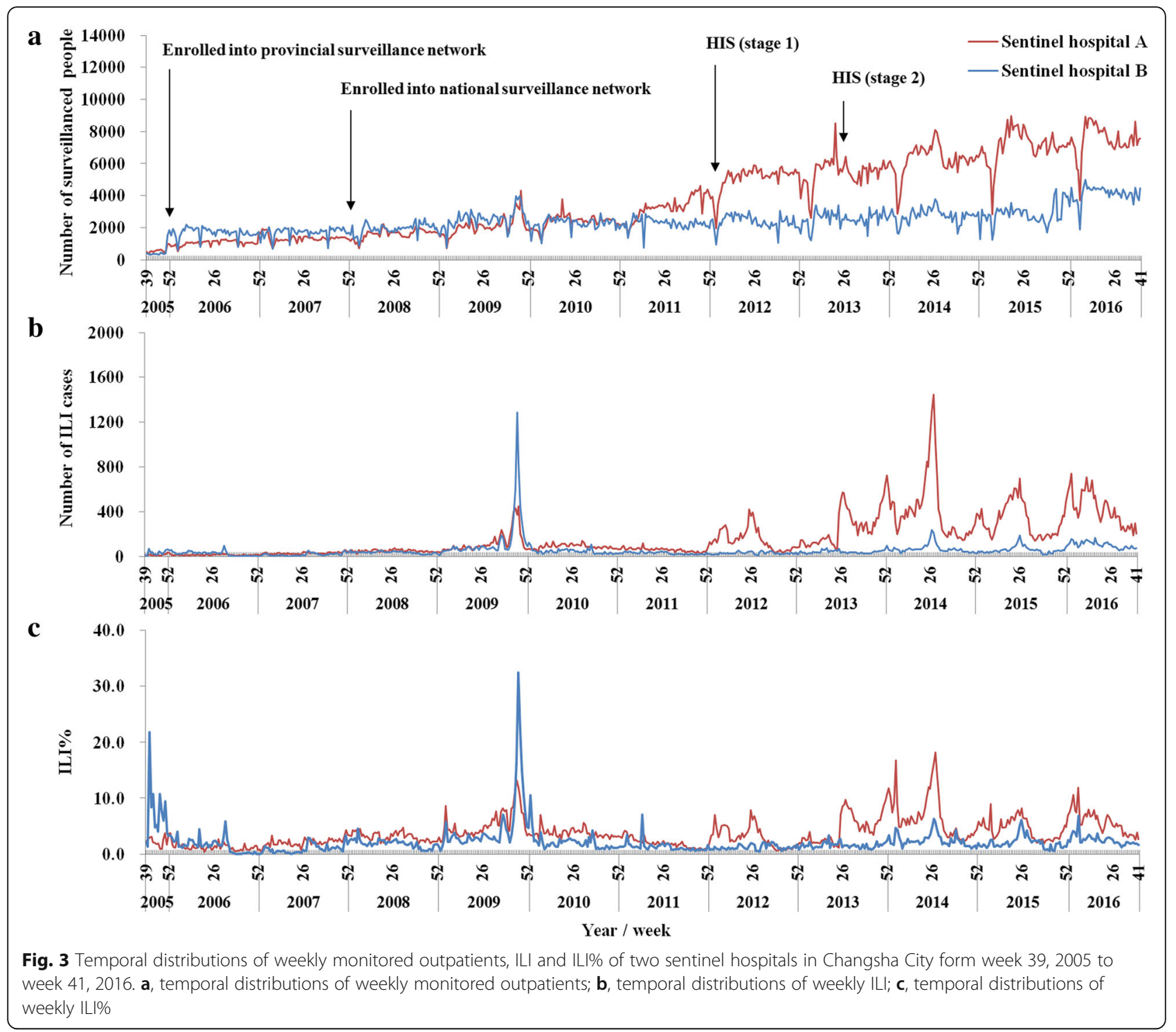

samples almost had same tendency in the two hospitals (Fig. 5). The inpatient cases on pneumonia ascended after "HIS (stage 1)" in hospital A (Fig. 6).

There was a total of 14,913 throat swabs collected from the two hospitals during the five surveillance stages, among which 2016 were tested positive to influenza or avian influenza virus. Among the positive results, there were 621 with H3N2, 135 with H1N1 (seasonal influenza virus), 610 with H1N1pdm (influenza A / H1N1 from 2009), 106 with untyped influenza $A, 540$ with $B, 1$ with H5N6, 1 with H7N9, and 2 with H9N2 virus. The numbers of influenza virus from the two hospitals were similar during the five stages. However, the outcomes of monitoring avian influenza virus were different between the two hospitals. In stage 4, one mild H7N9 case was captured in hospital A when the HIS was adopted at HIS (stage 1). In stage 5, one mild H5N6 case and two mild H7N9 cases were captured in hospital A when the HIS was adopted at HIS (stage 2) (Table 1).

\section{Pneumonia surveillance system}

From March, 2009 to September, 2016, there were 5, 491,560 inpatients monitored by the PSS system and 362,743 pneumonia cases, with the rate of $6.61 \%$. About $10.55 \%(38,260 / 362,743)$ of the cases reported on pneumonia were severe or death cases. The incidence of pneumonia increased each year in Changsha (Fig. 6). The seasonality of pneumonia was observed in spring (Fig. 6a).

We collected 3401 throat swab or lower respiratory tract samples, among which 2094 were tested positive to influenza or avian influenza virus. Among the positive results, 78 were $\mathrm{H} 3 \mathrm{~N} 2,17$ were seasonal $\mathrm{H} 1 \mathrm{~N} 1,1871$ 


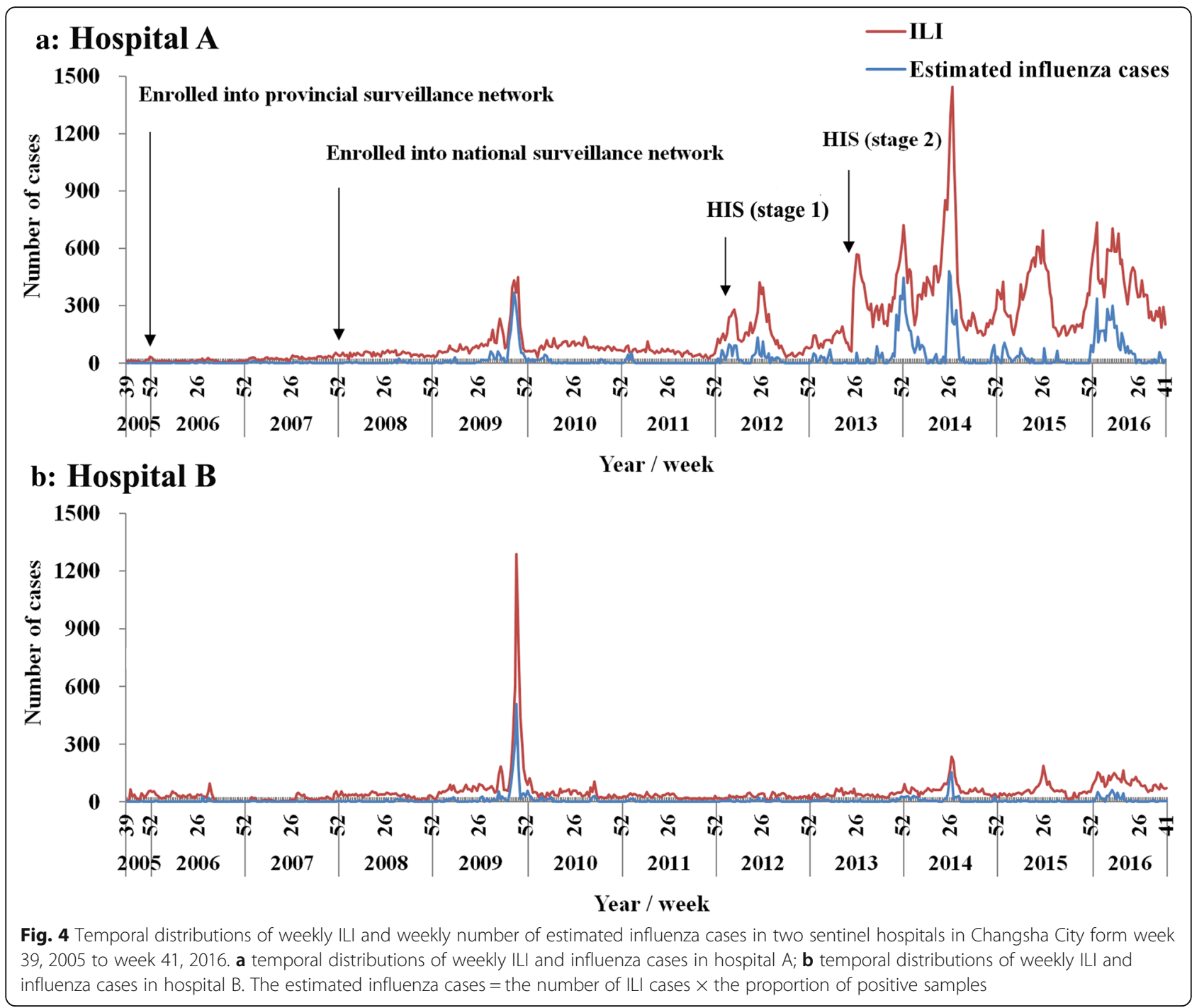

were $\mathrm{H} 1 \mathrm{~N} 1 \mathrm{pdm}, 103$ were untyped influenza A, 16 were $\mathrm{B}, 1$ was $\mathrm{H} 5 \mathrm{~N} 6$, and 8 were $\mathrm{H} 7 \mathrm{~N} 9$ virus. The activity of H7N9 virus and that of seasonal viruses especially H1N1pdm were observed in 2014 (Table 3).

\section{Emerging avian influenza cases}

There were 15 avian influenza cases reported from January, 2005 to September, 2016 (Table 4). Four cases were mild ones that were detected by the ISS system. Nine cases were severe or death cases that were detected by the PSS system. Two H5N1 severe cases were missed by both systems in January, 2009 when the PSS system was not available. Two H5N6 cases, of which one was mild case reported by the ISS system in 2014 and the other was severe case reported by the PSS system in 2016, were detected in Changsha. Nine H7N9 cases were reported by the two systems. One of them was mild case and was detected by the ISS system in 2013 and the other eight were severe / death cases detected by the
PSS system in 2014. Two H9N2 cases were mild cases and were detected by the PSS system in 2016 .

\section{Discussion}

The avian influenza viruses have spread to many countries including China, Thailand [26], Vietnam [27], Cambodia [28], Turkey [8], the Republic of Azerbaijan [9], Indonesia [29], and Egypt [10, 30]. To control the transmission of the disease, surveillance systems with high sensitivity and specificity need to be created. The surveillance system is commonly used for monitoring ILI for detecting avian influenza virus [30]. In Egypt, clinicians refer all persons with ILI and $<2$-week history of poultry contact to one of the Chest and Fever hospitals throughout the country. The respiratory samples of ILI cases are collected to test influenza virus. Daily respiratory samples are also collected from 2 ILI cases and from all patients admitted with severe acute respiratory infection (defined as hospitalization occurring 


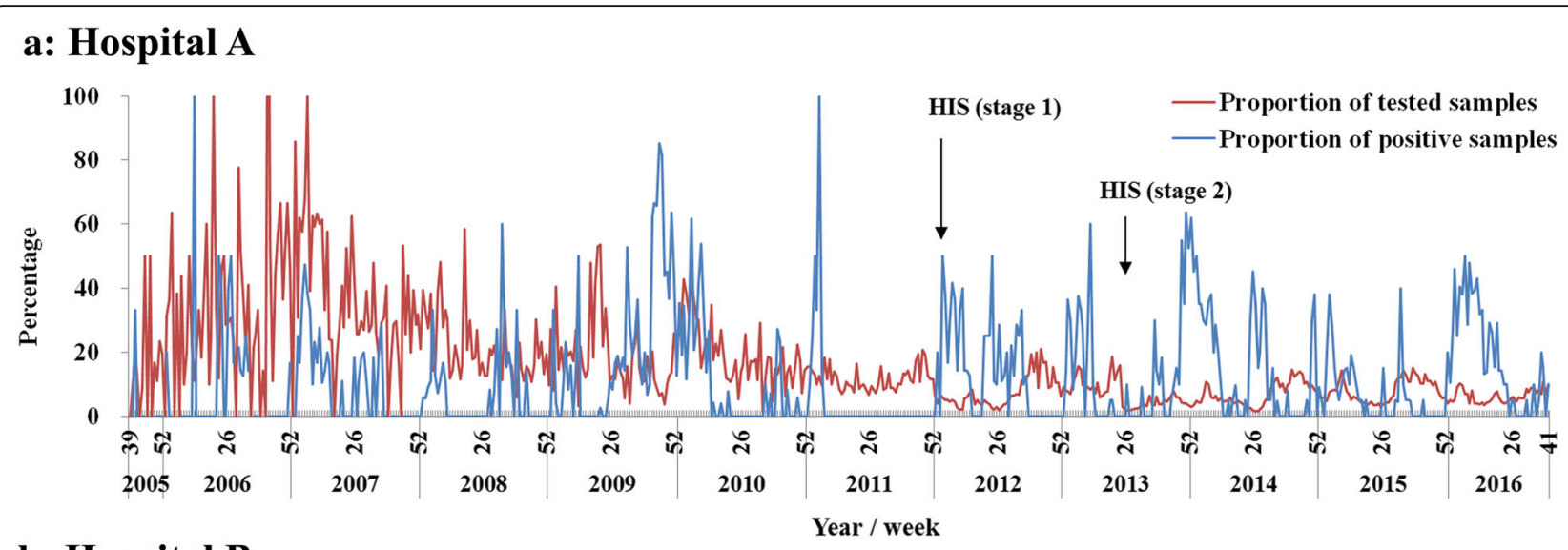

\section{b: Hospital B}

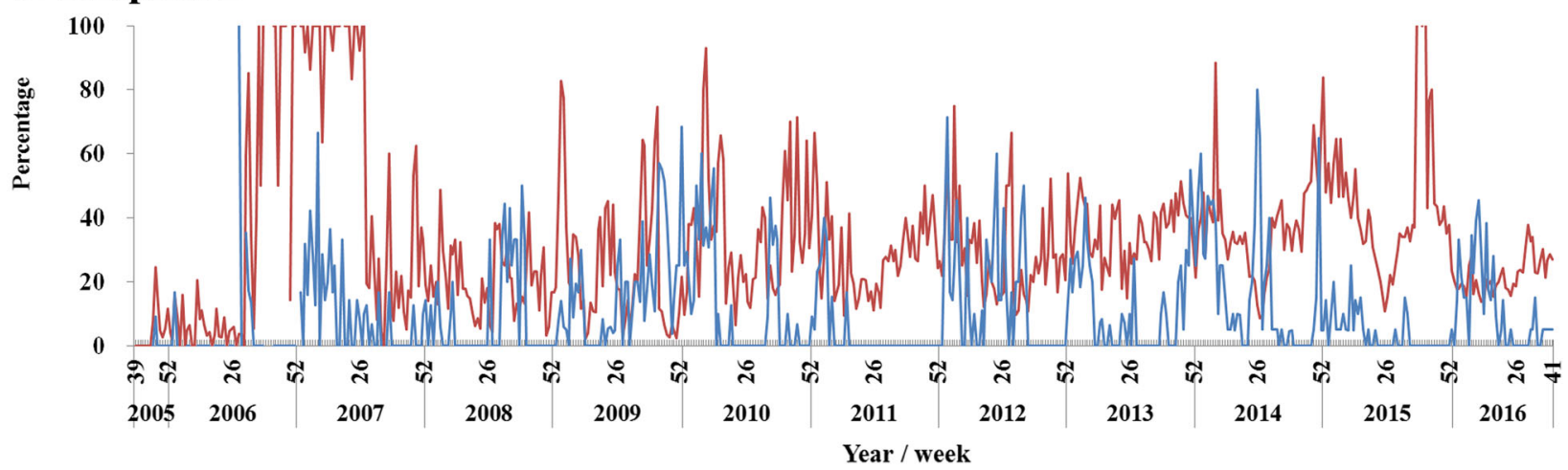

Fig. 5 Temporal distributions of weekly proportion of tested samples and weekly proportion of positive samples in two sentinel hospitals in Changsha City, week 39, 2005 to week 41, 2016. a Hospital A; b Hospital B

within 2 weeks of onset of fever and cough) in 8 sentinel sites [30].

In Changsha City, the ISS and PSS are different with the surveillance systems in Egypt. The ISS focuses on detecting mild cases while the PSS focuses on severe or death cases infected with influenza and emerging avian influenza viruses (Fig. 2). Therefore, the two systems together could monitor the viruses with different symptoms. The PSS, which covered by all secondary and tertiary hospitals in the city, is built primarily to monitor pneumonia cases. Therefore, the PSS could provide us with the data to estimate the burden of pneumonia and the pathogen spectrum of pneumonia including influenza and emerging avian influenza viruses.

According to our results, we found that the efficiency for monitoring ILI and emerging avian influenza virus was improved after the HIS was used in hospital A. The differences of ILI were significant between stages 1 to 3 and stages 4 to 5 , and between hospital A and hospital B after the HIS was used. All the mild emerging avian influenza cases (H5N6, H7N9, H9N2) were detected in the hospital A where the HIS was adopted. These results would encourage a higher coverage of the HIS and the quality of the influenza surveillance in China, to reduce the repetitive work of doctors and avoid bias from the manual counting. Moreover, the probability of finding out influenza and avian influenza virus would be higher than the existing surveillance system because more ILI cases would be recorded by HIS.

Because the ISS only focuses on the mild cases or the early stage of the infection, the surveillance of severe influenza or avian influenza cases is dependent on the PSS. The PSS is a system built in Changsha City and covers all the hospitals that have inpatient departments. Because the PSS focuses on pneumonia cases instead of PUE cases, the system might be more sensitive in detecting influenza virus and emerging avian influenza virus. The PSS has not only given us a way to estimate the disease burden of pneumonia cases in the city, but also has played an important role in controlling and preventing seasonal influenza each year, the pandemic of influenza A (H1N1) in 2009, and the emerging avian influenza such as $\mathrm{H} 5 \mathrm{~N} 6$ and H7N9 by detecting the severe cases of the infection with these viruses.

Co-infection of seasonal and avian influenza viruses was commonly observed [31]. However, the co-infection was not observed by the ISS in our study. But the activity of H7N9 virus and that of seasonal viruses especially 


\section{a: 49 hospitals}

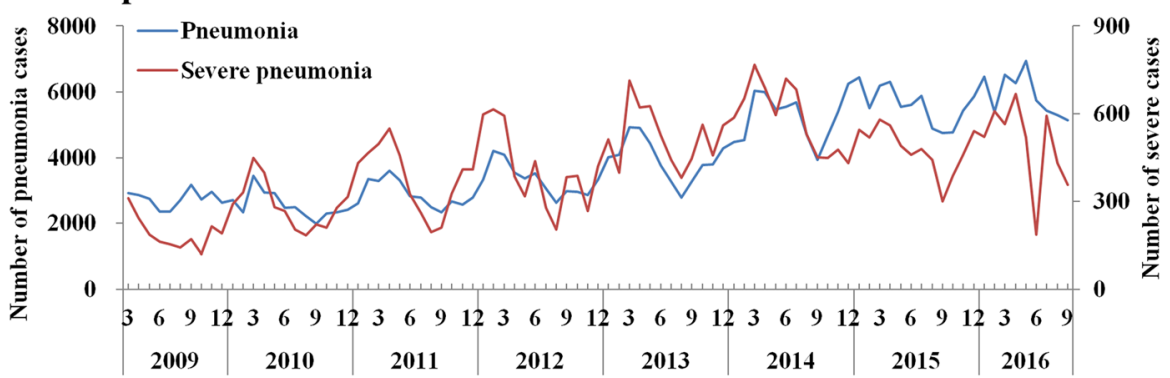

\section{b: hospital A}

Year/month

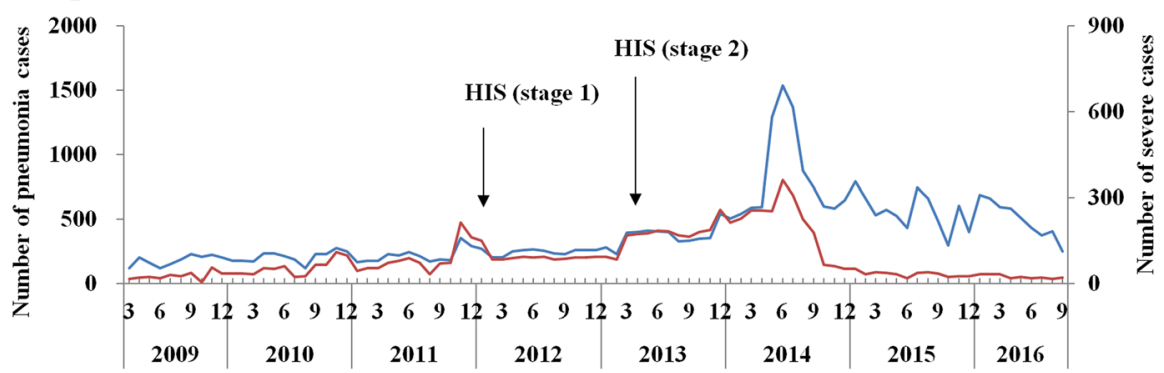

\section{c: hospital B}

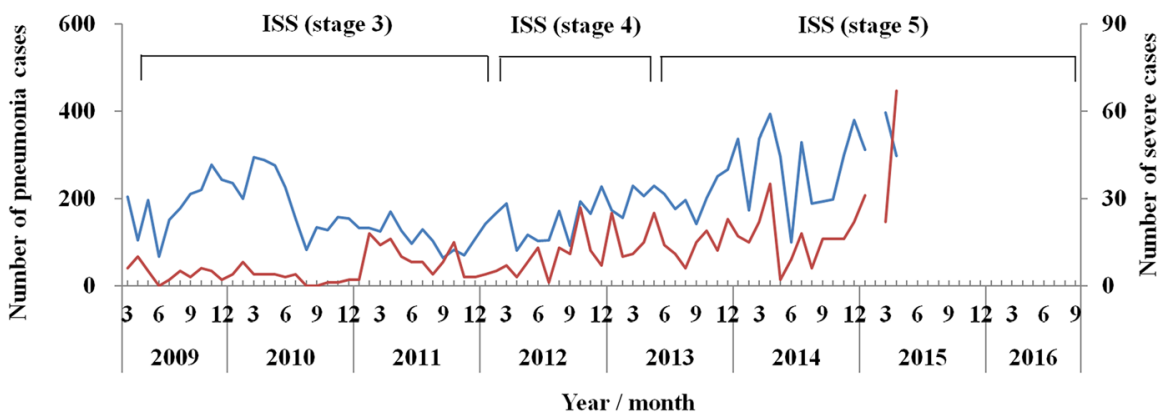

Fig. 6 Temporal distributions of pneumonia cases in 49 hospitals and two influenza surveillance sentinel hospitals in Changsha City, March, 2009 to September, 2016. a 49 hospitals; b hospital A; c hospital B

Table 3 Outcomes of pneumonia surveillance system in Changsha City, China

\begin{tabular}{|c|c|c|c|c|c|c|c|c|c|c|c|c|c|c|}
\hline \multirow[t]{2}{*}{ Year } & \multirow{2}{*}{$\begin{array}{l}\text { Surveilled } \\
\text { patients }\end{array}$} & \multirow{2}{*}{$\begin{array}{l}\text { Number of } \\
\text { pneumonia } \\
\text { cases }\end{array}$} & \multirow{2}{*}{$\begin{array}{l}\text { Number of } \\
\text { severe / death } \\
\text { cases }\end{array}$} & \multirow{2}{*}{$\begin{array}{l}\text { Number } \\
\text { of tested } \\
\text { specimens }\end{array}$} & \multicolumn{10}{|c|}{ Number of positive } \\
\hline & & & & & $\mathrm{H} 3 \mathrm{~N} 2$ & $\mathrm{H} 1 \mathrm{~N} 1$ & H1N1pdm & A (untyped) & B & H5N1 & H5N6 & H7N9 & H9N2 & Total \\
\hline 2009 & 394,683 & 27,388 & 1892 & 2944 & 69 & 17 & 1794 & 102 & 0 & 0 & 0 & 0 & 0 & 1982 \\
\hline 2010 & 650,244 & 30,503 & 3431 & 136 & 1 & 0 & 9 & 1 & 6 & 0 & 0 & 0 & 0 & 17 \\
\hline 2011 & 748,361 & 34,602 & 4537 & 142 & 0 & 0 & 29 & 0 & 5 & 0 & 0 & 0 & 0 & 34 \\
\hline 2012 & 820,482 & 39,831 & 4890 & 10 & 3 & 0 & 0 & 0 & 0 & 0 & 0 & 0 & 0 & 3 \\
\hline 2013 & 883,769 & 47,283 & 6250 & 29 & 0 & 0 & 0 & 0 & 0 & 0 & 0 & 1 & 0 & 1 \\
\hline 2014 & 798,792 & 62,726 & 7041 & 81 & 5 & 0 & 21 & 0 & 4 & 0 & 0 & 7 & 0 & 37 \\
\hline 2015 & 672,289 & 67,205 & 5765 & 16 & 0 & 0 & 0 & 0 & 0 & 0 & 0 & 0 & 0 & 0 \\
\hline 2016 & 522,940 & 53,205 & 4454 & 43 & 0 & 0 & 18 & 0 & 1 & 0 & 1 & 0 & 0 & 20 \\
\hline Total & $5,491,560$ & 362,743 & 38,260 & 3401 & 78 & 17 & 1871 & 103 & 16 & 0 & 1 & 8 & 0 & 2094 \\
\hline
\end{tabular}


Table 4 Avian influenza cases detected by different ways in Changsha City, China

\begin{tabular}{|c|c|c|c|c|c|}
\hline Avian influenza virus & Category of cases & Detected by ISS system & Detected by PSS system & Other ways & Total \\
\hline \multirow[t]{2}{*}{ H5N1 } & Mild cases & 0 & 0 & 0 & 0 \\
\hline & Severe / death cases & 0 & 0 & 2 & 2 \\
\hline \multirow[t]{2}{*}{ H5N6 } & Mild cases & 1 & 0 & 0 & 1 \\
\hline & Severe / death cases & 0 & 1 & 0 & 1 \\
\hline \multirow[t]{2}{*}{ H7N9 } & Mild cases & 1 & 0 & 0 & 1 \\
\hline & Severe / death cases & 0 & 8 & 0 & 8 \\
\hline \multirow[t]{2}{*}{ H9N2 } & Mild cases & 2 & 0 & 0 & 2 \\
\hline & Severe / death cases & 0 & 0 & 0 & 0 \\
\hline \multirow[t]{2}{*}{ Total } & Mild cases & 4 & 0 & 0 & 4 \\
\hline & Severe / death cases & 0 & 9 & 2 & 11 \\
\hline
\end{tabular}

ISS influenza surveillance system, PSS pneumonia surveillance system

H1N1pdm were observed by the PSS in 2014. This difference might be due to the limited number of reported avian influenza cases in the PSS.

\section{Limitations}

This study has several limitations. Firstly, in the surveillance procedure of the two systems, the tested samples were not chosen randomly, which might affect the surveillance outcomes and thus might impact our findings. Secondly, although the two systems have run stably for a long time and covered a large population, the number of avian influenza cases was limited. It still needs a longer time and a larger population to assess the sensitivity and specificity of the systems. In addition, the ISS system only covers two sentinel hospitals, and the coverage of the system should be improved. The missing PSS data in hospital B from late 2015 to 2016 might underestimate the ability of the PSS system in detecting the viruses. Limited by the small number of reported avian influenza cases in PSS, the co-infection of seasonal and avian influenza viruses might not be observed apparently. Our findings also showed that the number of severe pneumonia cases decreased significantly in late 2014 in Hospital A (Fig. 6). The reason for the decrease remains unclear, but the decrease might slightly affect the results of detecting influenza cases.

\section{Conclusions}

The HIS seems to be able to improve the efficiency of the ISS for monitoring ILI and emerging avian influenza virus. Although the PSS could monitor some emerging avian influenza viruses, the efficiency of the system needs to be verified in a wider area and in a longer time span in China.

\section{Abbreviations}

ANOVA: Analysis of variance; CDC: Center for Disease Control and Prevention; HIS: Hospital information system; ICD-10: International Classification of Diseases 10th Revision; ILI: Influenza-like illness; ISS: Influenza surveillance system; LSD: Least Significant Difference; PSS: Pneumonia surveillance system; PUE: Pneumonia of unknown etiology; RT-PCR: Reverse transcription polymerase chain reaction; SARS: Severe acute respiratory syndrome

\section{Acknowledgments}

We thank the staff members at the hospitals, local health departments, and municipal- and county-level CDCs in Changsha City for their valuable assistance in coordinating data collection. We thank Miss Mikah Ngwanguong Hannah in Medical College, Xiamen University for her English language editing.

\section{Authors' contributions}

$T C, B Z$, and $R L$ designed the research; RL, DY, YL, YLL, HZ, and $X Z$ collected the data; $T C$, and $X G$ conceived the experiments, $T C, X G, D Y$ and $R L$ conducted the experiments and analyzed the results; TC, $\mathrm{QH}$ and XM wrote the manuscript. All authors read and approved the final manuscript.

\section{Funding}

This study was partly supported by the Open Research Fund of State Key Laboratory of Molecular Vaccinology and Molecular Diagnostics (SKLVD2018KF001 and SKLVD2018KF002). The funding body had no role in the study design, collection, analysis, interpretation of data and in writing the manuscript.

\section{Availability of data and materials}

The datasets used and/or analysed during the current study available from the corresponding author on reasonable request.

\section{Ethics approval and consent to participate}

This effort of outbreak control and investigation was part of CDC's routine responsibility in Changsha City; therefore, institutional review and informed consent were waived by Medical Ethics Committee of Changsha Center for Disease Control and Prevention on the following grounds: (1) all data analyzed were anonymized.; (2) neither medical intervention nor biological samples were involved; (3) study procedures and results would not affect clinical management of patients in any form.

\section{Consent for publication}

Not applicable.

\section{Competing interests}

No authors declare a conflict of interest.

\section{Author details}

${ }^{1}$ State Key Laboratory of Molecular Vaccinology and Molecular Diagnostics, School of Public Health, Xiamen University, 4221-117 South Xiang'an Road, Xiang'an District, Xiamen, Fujian Province, People's Republic of China.

${ }^{2}$ Changsha Center for Disease Control and Prevention, Changsha, Hunan, People's Republic of China. ${ }^{3}$ Division of Public Health, School of Medicine, University of Utah, Salt Lake City, UT, USA. 
Received: 28 March 2019 Accepted: 25 August 2019

Published online: 18 September 2019

\section{References}

1. Chen H, Yuan H, Gao R, Zhang J, Wang D, Xiong Y, Fan G, Yang F, Li X, Zhou J, et al. Clinical and epidemiological characteristics of a fatal case of avian influenza a H10N8 virus infection: a descriptive study. Lancet. 2014; 383(9918):714-21.

2. Chen T, Zhang R. Symptoms seem to be mild in children infected with avian influenza a (H5N6) and other subtypes. J Infec. 2015;71(6):702-3.

3. Wu P, Peng Z, Fang VJ, Feng L, Tsang TK, Jiang H, Lau EH, Yang J, Zheng J, Qin $Y$, et al. Human infection with influenza a(H7N9) virus during 3 major epidemic waves, China, 2013-2015. Emerg Infect Dis. 2016;22(6):964-72.

4. Lai S, Qin Y, Cowling BJ, Ren X, Wardrop NA, Gilbert M, Tsang TK, Wu P, Feng $L$, Jiang $H$, et al. Global epidemiology of avian influenza a H5N1 virus infection in humans, 1997-2015: a systematic review of individual case data. Lancet Infect Dis. 2016;16(7):e108-18.

5. Peng Y, Li X, Zhou H, Wu A, Dong L, Zhang Y, Gao R, Bo H, Yang L, Wang $D$, et al. Continual antigenic diversification in China leads to global antigenic complexity of avian influenza H5N1 viruses. Sci Rep. 2017;7:43566.

6. Beigel JH, Farrar J, Han AM, Hayden FG, Hyer R, de Jong MD, Lochindarat S, Nguyen TK, Nguyen TH, Tran TH, et al. Avian influenza a (H5N1) infection in humans. N Engl J Med. 2005;353(13):1374-85.

7. Writing Committee of the Second World Health Organization Consultation on Clinical Aspects of Human Infection with Avian Influenza AV, AbdelGhafar AN, Chotpitayasunondh T, Gao Z, Hayden FG, Nguyen DH, de Jong MD, Naghdaliyev A, Peiris JS, Shindo N, et al. Update on avian influenza A (H5N1) virus infection in humans. N Engl J Med. 2008;358(3):261-73.

8. Oner AF, Bay A, Arslan S, Akdeniz H, Sahin HA, Cesur Y, Epcacan S, Yilmaz N, Deger I, Kizilyildiz B, et al. Avian influenza a (H5N1) infection in eastern Turkey in 2006. N Engl J Med. 2006;355(21):2179-85.

9. Gilsdorf A, Boxall N, Gasimov V, Agayev I, Mammadzade F, Ursu P, Gasimov E, Brown C, Mardel S, Jankovic D, et al. Two clusters of human infection with influenza a/H5N1 virus in the republic of Azerbaijan, February-march 2006. Euro Surveill. 2006;11(5):122-6.

10. Kayali G, Kandeil A, El-Shesheny R, Kayed AS, Gomaa MM, Maatouq AM, Shehata MM, Moatasim Y, Bagato O, Cai Z, et al. Active surveillance for avian influenza virus, Egypt, 2010-2012. Emerg Infect Dis. 2014;20(4):542-51.

11. Gao R, Cao B, Hu Y, Feng Z, Wang D, Hu W, Chen J, Jie Z, Qiu H, Xu K, et al. Human infection with a novel avian-origin influenza a (H7N9) virus. N Engl J Med. 2013;368(20):1888-97.

12. Zhang R, Chen T, Ou X, Liu R, Yang Y, Ye W, Chen J, Yao D, Sun B, Zhang X, et al. Clinical, epidemiological and virological characteristics of the first detected human case of avian influenza a(H5N6) virus. Infect Genet Evol. 2016:40:236-42.

13. Mok CK, Da Guan W, Liu XQ, Lamers MM, Li XB, Wang M, Zhang TJ, Zhang QL, Li ZT, Huang JC, et al. Genetic characterization of highly pathogenic avian influenza a(H5N6) virus, Guangdong, China. Emerg Infect Dis. 2015; 21(12):2268-71.

14. Yang ZF, Mok CK, Peiris JS, Zhong NS. Human infection with a novel avian influenza a(H5N6) virus. N Engl J Med. 2015;373(5):487-9.

15. Pan M, Gao R, Lv Q, Huang S, Zhou Z, Yang L, Li X, Zhao X, Zou X, Tong W, et al. Human infection with a novel, highly pathogenic avian influenza a (H5N6) virus: Virological and clinical findings. J Infect. 2016;72(1):52-9.

16. Huang Y, Zhang H, Li X, Hu S, Cai L, Sun Q, Li W, Deng Z, Xiang X, Zhang H, et al. Detection and genetic characteristics of H9N2 avian influenza viruses from live poultry Markets in Hunan Province, China. PloS one. 2015;10(11):e0142584.

17. Ip DK, Liao Q, Wu P, Gao Z, Cao B, Feng L, Xu X, Jiang H, Li M, Bao J, et al. Detection of mild to moderate influenza a/H7N9 infection by China's national sentinel surveillance system for influenza-like illness: case series. Bmj. 2013;346:f3693.

18. Xiang N, Havers F, Chen T, Song Y, Tu W, Li L, Cao Y, Liu B, Zhou L, Meng L, et al. Use of National Pneumonia Surveillance to Describe Influenza A(H7N9) Virus Epidemiology, China, 2004-2013. Emerg Infect Dis. 2013;19(11):1784-90.

19. Feng L, Shay DK, Jiang $Y$, Zhou $H$, Chen $X$, Zheng $Y$, Jiang L, Zhang $Q$, Lin $H$, Wang $S$, et al. Influenza-associated mortality in temperate and subtropical Chinese cities, 2003-2008. Bull World Health Organ. 2012;90(4):279-288B.

20. Guo Q, Hao F, Duan X, Xie X, Liao W. Multi personal computer storage system: solution of sea capacity PACS storage. Chin Med J. 2003;116(5):650-3.

21. Li P, Wu T, Chen M, Zhou B, Xu WG. A study on building data warehouse of hospital information system. Chin Med J. 2011;124(15):2372-7.
22. Chen T, Chen T, Liu R, Xu C, Wang D, Chen F, Zhu W, Zhang X, Yang J, Wang $L$, et al. Transmissibility of the influenza virus during influenza outbreaks and related asymptomatic infection in mainland China, 20052013. PLoS One. 2016;11(11):e0166180.

23. Chen TM, Chen QP, Liu RC, Szot A, Chen SL, Zhao J, Zhou SS. The transmissibility estimation of influenza with early stage data of small-scale outbreaks in Changsha, China, 2005-2013. Epidemiol Infect. 2017;145(3):424-33.

24. Cowling BJ, Lau MS, Ho LM, Chuang SK, Tsang T, Liu SH, Leung PY, Lo SV, Lau EH. The effective reproduction number of pandemic influenza: prospective estimation. Epidemiology. 2010;21(6):842-6.

25. Zhou Y, Lau EH, Ip DK, Nishiura H, Leung GM, Seto WH, Cowling BJ. Years of life lost in the first wave of the 2009 influenza a(H1N1) pandemic in Hong Kong. Am J Epidemiol. 2013;178(8):1313-8.

26. Ungchusak K, Auewarakul P, Dowell SF, Kitphati R, Auwanit W, Puthavathana P. Uiprasertkul M, Boonnak K, Pittayawonganon C, Cox NJ, et al. Probable person-to-person transmission of avian influenza a (H5N1). N Engl J Med. 2005;352(4):333-40.

27. Dinh PN, Long HT, Tien NT, Hien NT, le TQ M, Phong le H, Tuan le V, Van Tan $H$, Nguyen NB, Van Tu P, et al. Risk factors for human infection with avian influenza a H5N1, Vietnam, 2004. Emerg Infect Dis. 2006;12(12):1841-7.

28. Vong S, Ly S, Van Kerkhove MD, Achenbach J, Holl D, Buchy P, Sorn S, Seng $H$, Uyeki TM, Sok T, et al. Risk factors associated with subclinical human infection with avian influenza a (H5N1) virus--Cambodia, 2006. J Infect Dis. 2009;199(12):1744-52.

29. Smith GJ, Naipospos TS, Nguyen TD, de Jong MD, Vijaykrishna D, Usman TB, Hassan SS, Nguyen TV, Dao TV, Bui NA, et al. Evolution and adaptation of H5N1 influenza virus in avian and human hosts in Indonesia and Vietnam. Virology. 2006;350(2):258-68.

30. Refaey S, Azziz-Baumgartner E, Amin MM, Fahim M, Roguski K, Elaziz HA, Iuliano AD, Salah N, Uyeki TM, Lindstrom S, et al. Increased number of human cases of influenza virus a(H5N1) infection, Egypt, 2014-15. Emerg Infect Dis. 2015;21(12):2171-3.

31. Durand LO, Glew P, Gross D, Kasper M, Trock S, Kim IK, Bresee JS, Donis R, Uyeki TM, Widdowson M-A, et al. Timing of influenza a(H5N1) in poultry and humans and seasonal influenza activity worldwide, 2004-2013. Emerg Infect Dis. 2015;21(2):202-8.

\section{Publisher's Note}

Springer Nature remains neutral with regard to jurisdictional claims in published maps and institutional affiliations.
Ready to submit your research? Choose BMC and benefit from:
- fast, convenient online submission
- thorough peer review by experienced researchers in your field
- rapid publication on acceptance
- support for research data, including large and complex data types
- gold Open Access which fosters wider collaboration and increased citations
- maximum visibility for your research: over $100 \mathrm{M}$ website views per year
At BMC, research is always in progress.
Learn more biomedcentral.com/submissions 